PROCEEDINGS OF THE GEOLOGICAL SOCIETY.

Channel to such limits as it has now, and the final opening of a communication with the North Sea, must have taken place subsequently to this same brickearth-period.

\title{
On the Geology of VARNA, and the Neighbouring parts of
} Bulgaria. By T. Spratt, Capt. R.N., F.R.S., F.G.S.

[Read June 18, 1856.]

Varna and the Coasts to the South.-The Varna district seems to consist generally of two distinct formations : viz. 1st, a series of yellowish and grey deposits, composed of calcareous sandstone and sandy marls, with sometimes an oolitic bed interstratified; 2 ndly, a series of arenaceous marls, sands, and fine gravel, of a reddish-brown and greyish colour, which overlie the former, and occupy the tops of the ridges, or occur on the sides of some of the valleys.

The lower group is marine and appears to be of the Eocene Tertiary age ; it attains a thickness of fully 1000 feet in some localities. The overlying red sands and marls are seldom found in greater thickness than from 100 to 200 feet in the immediate vicinity of Varna; having been no doubt much denuded from that district. On the coast, however, at Cape Aspro, about fifteen miles south of Varna, and ten miles north of Cape Emeneh, the termination of the Balkan, the cliffs show a section of the two series of deposits together, as seen in the following sketch (fig. 1). A local disturbance has here tilted

\section{Fig. 1.-Section at Cape Aspro.}

s.

Cape Aspro, N.

a. Brown and reddish sandstones and marls (Freshwater).

$b$. White calcareous sandstones and marls (Marine).

the two formations to a greater inclination than usual, and exposed a thickness of fully 1000 feet of the red sand and marls.

This coast-section shows that the two groups are unconformable; the lower, and evidently marine series, dipping to the southward, at an angle of nearly $30^{\circ}$; whilst the red sands and marls, which are probably partially, if not wholly, of freshwater origin, overlie them at an angle of about $20^{\circ}$.

Cape Aspro is so called from the whitish colour of the cliffs that commence at this cape and extend northward along the whole const to Cape Kaliakrâ and Cape Shablur, and present everywhere the yellowish white marls and calcareous strata; varying, however, in some few localities, by the more marly and less calcareous nature of some of the beds; but all lying nearly horizontal.

To the southward of Cape Aspro, the disturbances in the deposits increase with the increasing elevation of the ridges, as they approach the Balkan: and the sections exhibit occasionally some of the shales and schistose rocks of an older formation; until at Cape Emeneh, 
the termination of the Balkan range, we have these strata appearing almost vertical, under the monastery that stands upon the Cape. The strata dip here to the northward, as seen in the accompanying sketch (fig. 2), taken from the sea while passing.

Cape Emeneh.

Fig. 2.-Section at Cape Emeneh.

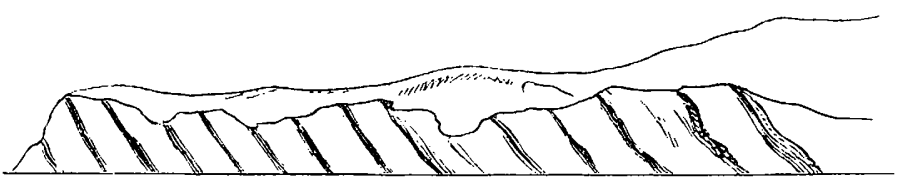

Some two or three valleys were briefly examined by me on the south side of the Cape towards Monembasia ; but I could find no fossils in the shales at either of them. In mineral character they greatly resemble the shales of the Bosphorus.

The shores of the Gulf of Bourgas, from Monembasia to Bourgas, are lined with low flat hills, composed of red unfossiliferous marls, from 40 to 60 feet in thickness, and apparently of recent and perhaps volcanic origin, since on the south shore of the gulf there are evident volcanic productions, which appear to be partially of a late geological age.

The Island of Anastasia (or Papas, as it is sometimes called, from the monastery upon it) is composed of an indurated volcanic mud, which contains quartz-crystals, like a porphyry. It is of a reddish or rusty-grey colour, and is stratified; but with irregular strata. The points and the coast adjacent to the island, and to the westward, are composed of yellowish and brown marly sand, about 30 feet in thickness, overlying reddish volcanic rocks, similar to those of Anastasia ; with conglomerates of serpentine and other igneous productions. The reddish marls overlying the latter seem to have been derived from the waste of the volcanic rocks; and to have been deposited in quiet but muddy waters.

The point to the east of St. Anastasia, towards Liziopoli, as well as the hills south of it, are composed entirely of granite, and probably are of much older origin than the serpentine-conglomerates and the indurated and contorted strata of the Island of Anastasia.

Varna Bay and the Lakes at Allahdyn.--Returning to the neighbourhood of Varna, - the cliffs are composed of the yellow and white calcareous strata and sandy marls, here containing abundant fossils ; chiefly the casts of marine shells, both univalves and bivalves; but the specimens are too fragile to be preserved. There are, however, Oysters and Pectens perfect. I could find no Nummulitoid shells in the deposits immediately around Varna; but at the upper part of the lake near Allahdyn, where the formation seems to be the same in general mineralogical age, character and size, Nummulites are most abundant ; particularly in the cliff close to the watering-place of the Light Division, when encamped there. Over Kepedjeh also, on the 
south side of the river connecting the two lakes, the Nummulites were equally abundant.

At both these localities the formations consisted of a series of calcareous sandstones, of very fine grain, which pass sometimes into a compact limestone, several feet in thickness : but this is partial ; in general the more durable stone is confined to the uppermost strata in this neighbourhood, and attains a thickness of 20 and 30 feet; beneath which are white arenaceous marls and sandstones with oolite, which together are fully 1000 feet thick near Devno.

The upper and more indurated stratum is here composed of a mass of organic remains, chiefly Nummulites, Operculina, and Orbitoides, in all ages of growth; with Pecten, Terebratula, and an Ostrea with a very thick shell; as seen in the specimens forwarded *.

Columnar condition of the Nummulitic Rocks at Allahdyn.-Connected with the highly fossiliferous condition of the upper existing stratum of this deposit, a curious feature has resulted from the manner in which the rock in some places has apparently become weather-worn into vertical pillars.

A large group of these columnar masses exists about a mile and a half north of the ground occupied by the Light Division and close to the upper Shumla road, see fig. 3. When I visited the camp, they were generally believed to be artificial, such as relics of a rude temple of some early people. Certainly a passing glance might easily lead to the idea of their having been formed by man for some such purpose. But a close investigation, showing their irregularity in position, shape, and height, clearly indicates that they are not artificial, as Col. Hamilton, of the Grenadier Guards, has already stated + . For there are some partially formed in some of the rocks in the vicinity, as seen in a pair that are nearly formed out of a detached mass of rock over the village of Kepedjeh on the south side of the plain dividing the two lakes. In this instance the accidental hardness of the upper portions has hitherto retained the two columns united. The resemblance of this mass of rock to a Cromlek or a Druidical altar, together with the rude columnar masses scattered over the country near, is naturally suggestive of their having some connexion with the earlier worship of the East. They may indeed have been so used, from their adaptation to the religious ideas and worship of an earlier people; but certainly they were not the erection or the work of man. They are, in my opinion, natural productions, and having, as such, a geological interest, I am induced to give two sketches $\ddagger$ of the group near Allahdyn and to dwell more upon them. p. 82.

* For a list of the fossils accompanying this communication, see Appendix, $\dagger$ Quart. Journ. Geol. Soc. vol. xi. p. 10.

$\mp$ Fig. 3 is a reduction from the author's original sketch of the northern half of the group of columns at Allahdyn; with the exception of the characteristic column on the right-hand foreground of the engraving, which has been transferred from the author's sketch of the southern portion of the group. 
Downloaded from http://jgslegacy.lyellcollection.org/ at University of California-San Diego on July 6, 2016

SPRATT-BULGARIA.

Fig. 3 .

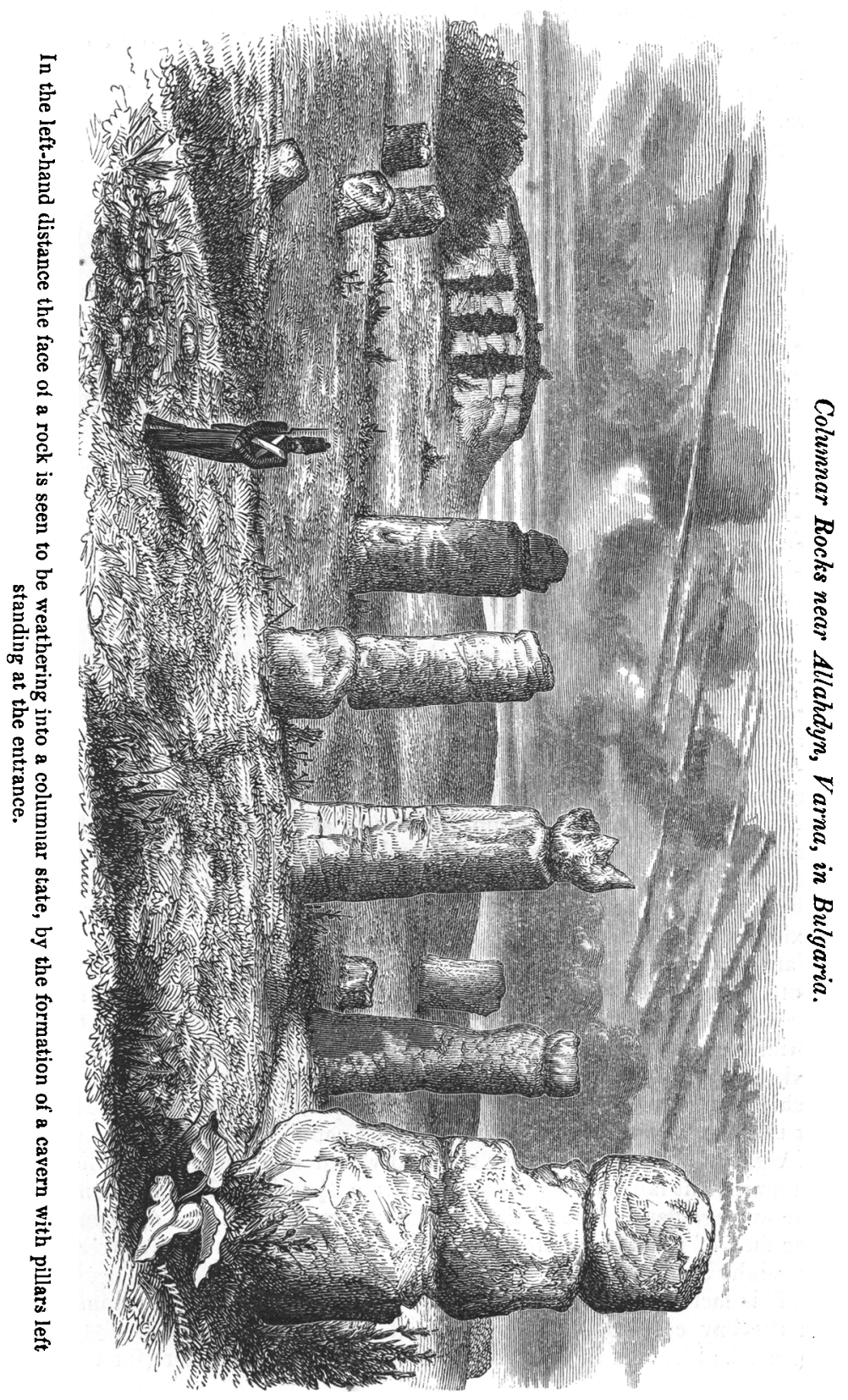


The surface of the rock in the vicinity of these columnar masses is, I observed, sometimes much split into vertical cracks, causing the portions denuded of soil to bear some resemblance to an open pavement of flat slabs.

The atmosphere and rain, probably, operating together in those rents early exposed, wearing down the sides and angles, and increasing the openings, have finally left the hardest portions standing as isolated columnar masses, or reduced to detached spherical nodules. The contained fossils have, from their greater hardness, resisted the degradation, which probably was more chemical than mechanical ; and the Nummulites, so abundant in the stratum from whence the columnar masses were derived, having thus become detached, may be gathered in great quantities at their bases. At the small group of columns over Kepedjeh, this nummulitic sand is so thickly strewed, together with rounded nodules of the limestone, as to resemble the dry bed of a river, although situated upon the slope and top of the ridge.

Similar conditions exist in every group of the columnar rocks that I saw in the neighbourhood: they are derived, as I before noticed, from the uppermost remaining deposit of the Lower Marine Tertiaries at this locality, which is, in the vicinity, immediately overlaid by the reddish-brown sandy marls of the second series of deposits which I have noticed.

The rounded and apparently water-worn character of these columnar masses and nodules, and their existence on the surface of the Marine Tertiaries, are suggestive of their having originated at so early a period as the time intermediate between the two groups of deposits, and during some moving condition of the covering waters at that period. I am not prepared to deny this ; for it seems very probable ; although my impressions on the spot were always favourable for an origin, degradation, and waste at a recent period, and in fact now in process, under the atmospheric influence.

But in support of their older origin, I am induced to mention a curious fact, that seems to support this idea; viz. the apparent existence of a corresponding group of columnar rocks in the Bay of Varna, which rise up in pinnacles from 5 to 8 and 9 feet above the bottom. They were not discovered in sounding the bay until it became crowded with our transports upon the preparation for the Crimean expedition. No one at the locality was aware of their existence, until the hawsers of an English transport and the chaincable of a French brig, anchored near the spot, were found entangled at the bottom amongst what the French captain expressively called "A group of columns ;" for the lead would not remain upon their summits, but fall, as I myself proved, from $3 \frac{1}{2}$ fathoms into 5 fathoms, the average depth around them. A diver sent down by me confirmed the fact of their being elevated pinnacles of rock; and not a wreck, as might be imagined.

This fact seems to suggest the occurrence of a group of columns in the bay corresponding to those at Allahdyn: and thus, if the former be identical in respect to the deposit with the latter (for they 
must have been also covered subsequently by the group of red marls, \&c., and entirely denuded again), we have the fact or idea of the Devno Valley and Varna Bay having been formed by a depression of comparatively recent date.

North of Varna.-I shall now make a few remarks upon the deposits lying north of Varna, towards the Danube and the Dobrudcha. A line of steep banks or cliffs extends from Varna to Cape Kaliakrâ, which are everywhere formed of the yellowish limestone and sandy marls, with a thickness of from 400 to 500 feet; and this group extends to near Mangalia, where the overlying reddish sands and marls take their place, and form generally the Steppe-country of the Dobrudcha. The ridges or plateaux of the latter district attain generally an elevation of between 200 and 300 feet, as in the direct line across from Kustenjeh to the Danube. On this line, rocks of the older Tertiary period are exposed at the base of the reddish marls and sands, on the edge of the lower Korason Lake, but are not seen on the Black Sea shore of the Dobrudcha. At Baljik the edge of the steppe is nearly 600 feet above the sea.

These deposits are generally less indurated than at Varna, and are, for the most part, more marly, passing, in some strata, into an indurated calcareous marl. The upper portion, for nearly 100 feet, is a white and grey marl, of fresh-water origin, and apparently conformable with, or passing gradually into, the marine deposits below ; both being nearly horizontal. The freshwater deposits appear to have resulted from the waste of some of the former, although somewhat more sandy. Land-shells are also found in some of the overlying beds of white arenaceous marls above the purely freshwater deposits. The whole are here capped by a few feet of a red earthy marl, that seems to belong to the second group of deposits, usually red or brown; and to connect those below, of freshwater origin, with them also.

[In a letter* received since this paper was read, Capt. Spratt saysHaving touched at Baljik for two or three hours in August last, I had an opportunity of making additions to my former account of its formations. I found the general distribution of the strata to be as follows:-

At the base are 150 or 180 feet of dark-grey and brownish marls, thinly laminated, and containing numerous marine fossils, generally very minutet. These marls form apparently an upper member of the Varna series. They lie nearly horizontal, and are overlaid by about 200 feet of a white thick-bedded marl, containing only casts of a small striated bivalve, like a Cardium, especially like the one in the freshwater deposits of the Dardanelles.

This mass of white chalky-looking marl seems to be unconformable to the lower marine bed, although nearly horizontal also. I think that probably it is of brackish-water origin : it passes upwards into a series of white and greyish marls, indurated occasionally in

* Read at the Evening Meeting, December 3, 1856.

+ A small packet of this shelly deposit has been brought to England by a friend of Capt. Spratt. The shells are small, and prove to be Trochus, Buccinum, Bulla, 
thin strata, which are replete with freshwater shells, associated sometimes with the above-mentioned Cardium.

These are also from 150 to 200 feet in thickness, and the fossils belong to the genera Planorbis, Limnae, Paludina, Cyrena, and Cyclas?, with abundant specimens of Helix in the upper 40 or 50 feet of the series. The whole is capped by a fragment of reddish earthy marl, only a few feet thick.

Capt. Spratt also remarks, -

I have satisfaction in stating that my idea of the reddish and grey sands and marls of the Dobrudcha (Kustenjeh, \&c.) being of freshwater instead of marine origin or "drift" was made somewhat more evident by a recent examination and visit to Kustenjeh, where I found the lower bed of grey marl or clay to contain a fragment of an Ele-

Fig. 4.-Section of the Strata at Kustenjeh, Black Sea.

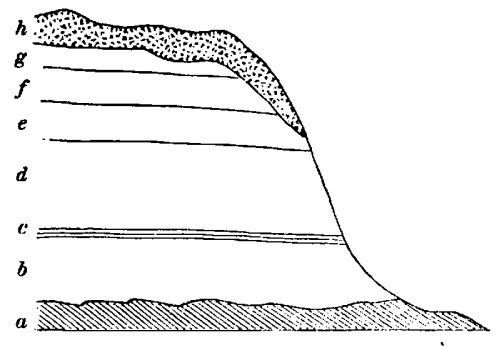

a.-4 to 6 feet of oolitic yellowish-white limestone with fossils, probably a member of the nummulitic series, and very like the Varna and Sebastopol rocks. (This was not seen by me in 1853.) It dips $8^{\circ}$ or $10^{\circ}$ to the N.E.

b. -12 to 15 feet of unconformable greyish marl or clay, with an Elephant's tusk. c.-Gypseous bands with casts of Cyclas or Cyrena.

d.-25 to 30 feet of reddish marl, with nodules of gypseous crystals, but no fossils. It passes into

e.-About 12 feet of reddish-black earthy clay, which is without apparent stratification, except of colour, and passes into

$f$ and $g$.- Reddish-grey and whitish-grey sandy marl, from 20 to 30 feet thick, very like the alluvial mud formed by the Danube, and without fossils.

h.- Superficial soil with pottery.

This section gives a good idea of the soft superficial deposits extending through the Dobrudcha.

Rissoa, Cardium, \&c. There are also numerous Foraminifera, of which the following is the list :-

Lagena.

Entosalenia.

Rosalina Beccarii.

Nonionina granosa.

Polystomella crispa (presenting numerous varieties, and constituting the majority of the foraminifers in this deposit).

Excepting the Articulina, these Foraminifera appear to be those commonly met with in shallow waters.-ED. Q. G. J.

\section{Textularia.}

Amorphina (Parker, MS.).

Spiroloculina.

Quinqueloculina.

Triloculina.

Articulina. 
phant's tusk, and a few feet above it an indurated stratum of gypseous bands, with impressions of a shell much like a Cyclas or Cyrena, and apparently such as I found in the Dardanelles deposits. They are not drifted shells, but were tranquilly imbedded in the bed of the lake in which they lived. This band passes into beds of grey-reddish and greyish-white porous earthy marls and clay, more stratified by colour than by change of mineral character. Fig. 4 is a section of these deposits.

I wish it to be understood (continues Capt. Spratt) that I am not confounding any member of the "northern drift" with fluviatile or lacustrine deposits, although I think that has been frequently done in describing some of these late freshwater formations in which gravels are found.

But that there are evidences of a "drift" of a very late period I am aware; and I think the formation at Gallipoli (Sea of Marmora) to be an example. This is a bed of coarse gravel cemented into a hard conglomerate, in which the valves of a large species of Dreissena and a Cardium are abundantly intermixed; the mass being more than 100 feet thick. There is another fragment of it over Nazara Point, near the Dardanelles Castles, and capping the freshwater marls and sands which dip to the eastward, whilst the mass of conglomerate dips to the south-west.

On the north shore of the Sea of Marmora the "drift" is shown by a mass of cemented valves of Driessena, intermixed with only a few small pebbles.

$$
\text { T. S. October 1, 1856.] }
$$

Comparison of the Geological Features of Bulgaria and the Crimea.-I merely give these facts from a hasty examination during war ; and present a series of the fossils I procured to the Society. Future researches, or the observations already made by others, but which I have not had the opportunity or time to inquire into, may perhaps explain the relative ages and peculiarities here touched upon.

Taking, however, a general view of the geological facts here briefly given, we have the secondary rocks of the Balkan terminating over the shore of the Black Sea at an elevation of nearly 2000 feet, and, with the formations lying to the north, presenting geological features similar to those of the Crimea. For, extending from the roots of the Balkan, we have the older marine Tertiaries inclining gradually from them, and succeeded by a broad district composed of reddish marls and sands, forming the Steppe of the Dobrudcha, as along the north parts of the Crimea. There is a remarkable resemblance in the red marly cliffs that extend from the Balbek in the Crimea, along the whole coast to Eupatoria, and repose directly upon the old Tertiary deposits of the Khersonese and Sevastopol, with the second group of deposits on the coast of Bulgaria. I have examined these deposits at Eupatoria, at Old Fort, at the Alma Heights, at the Katcha, and on the north side of the Balbek, and was struck with the similarity of their mineral character and with the absence of fossils, as in those of the Dobrudcha. 
In Demidoff's Geological Map of the Crimea, the formation in this district is referred to a Tertiary of the Miocene age, which I much doubt; at any rate, it is numbered and coloured the same as the western half of the Khersonese, with which it certainly does not agree in geological characters or age.

Thus we have, as I have shown, a close resemblance in the deposits of the opposite shores of the Black Sea,-that is, of the Crimean and the Bulgarian coasts, although an exact geological correspondence in respect to age has not been yet made out. We have, however, an evident submarine connexion of the two mountain-ranges of the Balkan and the Tauric Peninsula, traceable across the Black Sea in a line between them. For from Odessa we have a shallow sea, increasing out from 10 to 40 fathoms only a little north of this line, -forming in fact a gradually inclined bank, until its edge descends suddenly from 300 feet to 3000 and upwards*, as on the south face of the Tauric Range; thus showing the evident continuity of the great displacements of the older formations, by which the Balkan and the Crimea were elevated. This submarine plateau or steppe is thus the link connecting the Balkan with the Caucasus as a topographical feature.

It was along the margin of this submarine plateau that the electric cable connecting Bulgaria with the Crimea was laid, so as to take advantage of its convenient depth, instead of risking an accident over the deep region of the sea in a direct line across ; for the edge of the bank forms a slight curve to the north-west of the direct line.

The freshwater deposits. - The freshwater deposits overlying the marine above Baljik are deserving a special remark; because, from their position, they seem not to have been formed in a very limited lacustrine basin. Their absence, however, at Devno would rather imply the contrary; but it is possible that they have been denuded from that locality.

The real age of the overlying red marls, \&c. has yet to be determined. I am led to remark, however, that they bear some resemblance to the freshwater deposits on the north shore of the Sea of Marmora, at Buyuk Tchekmejeh ; and also very much so with those forming the lesser hills along the Macedonian coast, from Salonica, and also in the north end of Euboa and the Locrian shore; fossils from which have been long since given by me to the Museum of Economic Geologyt. The localities from whence these fossils came have not yet been described $\ddagger$; but the corresponding deposits are noticed as a group of "brownish sandy marls and gravels" overlying the Eocene freshwater beds of Samos and Eubœa, in a paper by me, published in the Geological Society's Journal $\S$ of 1847.

\footnotetext{
* Since ascertained to descend abruptly from 50 to 500 or 600 fathoms, or nearly 4000 feet in depth : and in the middle of the western basin of the Black Sea the depth has been ascertained by me to be nearly 7000 feet, or nearly twice that of the Tauric range in the southern part of the Crimea. [T. S., October, 1856.]

+ Amongst them is Limncea Adelina in great abundance.

$\$$ Since this paper was read, Capt. Spratt has communicated a description of the deposits here referred to, in his memoir "On the Freshwater Tertiaries of Eubca," \&c., read Dec. 17, 1856.-EDrT. Q. G. J. $\S$ Vol. vii. p. 70.
} 
I had at that time found no fossils in any of these largely-developed deposits of red sandy marls, \&c. ; but I subsequently identified their freshwater origin, as evidenced by the fossils found near Talanta on the Locrian coast, where all the lesser hills are composed of these deposits, also at Thermopoli, the valley of Xero Khori (Eubœa), and along the Macedonian coasts up to Thessalonica, where I found them to contain freshwater fossils, the bones of a Snake (afterwards given to Prof. Owen), and also some Mammalian bones, which were sent to the Museum in Jermyn Street*. The localities deserve a brief description (which I hope to give hereafter), from their evident connection with the Pleiocene freshwater deposits of Lycia, Rhodes, and Cos, and with some in Crete also ; and, I think I may add further, with the extensive freshwater deposits that occur on both sides of the Dardanelles from the Troad to Gallipoli, and along the coast of the Sea of Marmora, where they contain thin beds of lignite + in some places, as at Buyuk 'Tchekmejeh.

Almost all the Thracian Peninsula, indeed, is composed of deposits of freshwater origin, consisting of brown and grey marls and sandstones, or sands, lying nearly horizontal and attaining a thickness apparently of fully 500 and 600 feet; and, from their fossils, they seem to be of a type corresponding with the latter or Pleiocene freshwater deposits on the western side of the Archipelago, in Eubœa, and Macedonia, and in Rhodes, \&c. on the south.

The specimens sent to the Society from the deposits on the north side of the Dardanelles will best determine this ; they consist of a Cyclas, Paludina, Planorbis, Melanopsis, \&c., and there is a cast of some large Seed-vessel with them, resembling a pine-fruit; this was procured from above Meitos. The deposits immediately over the Europe Castle of the Dardanelles, Killid Bahr, contain fossils in the greatest abundance ; but, excepting the species of Melanopsis herewith sent, these are generally too fragile to be preserved perfect.

The inquiry as to the boundaries of these freshwater lakes, if they were a chain of lakes, or its range and extent if there were but one large lake, still forms a very interesting subject of research connected with the geology of the Egean, the Sea of Marmora, and the Black Sea.

Post-Tertiary or Recent deposits.-On several parts of the shores of the Dardanelles there are the remains of a recent marine deposit, indicative of a change in the present sea-level since it succeeded the Pleiocene lake above referred to. For at the base of the hills north of Meitos, and on the opposite coast, there are Oyster-beds at an elevation of about 40 feet above the sea.

These Oysters correspond exactly with those now existing plentifully in the chammel near Meitos, which are largely exported to Con-

\footnotetext{
* These fragmentary mammalian bones were submitted by Prof. E. Forbes to Prof. Owen, but were not determinable. The ophidian vertebre have been described in a paper read before the Society by Prof. Owen, Jan. 7, 1857, who referred them to an extinct, and previously undescribed genus, Laophis.-EDiT. Q. G. J.

+ For a notice of the occurrence of lignites in the north-western districts of Asia Minor, see this Journal, no. 45, p. 1.-EDrT. Q. G. J.
}

VOL. XIII. - PART I. 
PROCEEDINGS OF THE GEOLOGICAL SOCIETY.

stantinople, \&c. The sea-level no doubt was 15 or 20 feet higher than the Oyster-bank, as this does not appear to have been a beach.

At Gallipoli, also, there are the remains of an old sea-bed, forming the crest of the Point near the Lighthouse, and containing great quantities of a large Cardium, apparently the existing species, and with it $I$ found intermixed the detached valves of a Dreissena (see specimens sent to the Society), which were probably washed out of the freshwater deposits that this recent sea-bed overlies : its elevation is about the same as of that at Meitos.

\section{Appendix.}

Mr. J. Morris has kindly assisted the Editor in drawing up the following rough list of the fossils accompanying Capt. Spratt's Notes on the Geology of Varna, the Bulgarian Coast, and the Dardanelles.

\section{Fossils from Allahdyn. (See page 73.)}

\section{Mollusca.}

Teredo?

Ostræa latissima, Deshayes.

Ostrææ; small species.

Anomia.

Plicatula?

Pecten; two species.

Terebratula ; resembling T. carnea.

$$
\text { Annelida. }
$$

Vermicularia ; like V.Bognoriensis.

Serpula.

$$
\text { Entomostraca. }
$$

\section{Foraminifera.}

Nummulina distans, Deshayes.

N. (Assilina) granulosa, D'Archiac ; (nearly smooth var., rare).

Operculina canalifera, D'Archiac; (very fine specimens).

Orbitoides Fortisii, D'Archiac.

Cristellaria rotulata, Lamarck, sp.

Truncatulina vulgaris, D'Orb.

Nonionina communis, D'Orb.

Rosalina ammonoidea, Reuss.

Bairdia subdeltoidea.

Cythere, sp.

\section{Fossils from Varna Bay. (See page 73.)}

Trochus.

Buccinum or Nassa.

Pecten.

Chama.

Cerithium.

Casts of small univalves and bivalves.

Lucina.

Modiola (a ribbed species).

Cardium (in the oolitic rock).

\section{Baljik; greyish crystalline limestone.}

Planorbis.

Limnæa.

Hydrobia?
Helix? (fragment).

Cyrena? (fragment).

4. Baljik; soft white calcareous rock.

Helix; a small depressed species.

Mactra.

$$
\text { 5. Baljik; soft white calcareous rock. }
$$


SALTER-CRETACEOUS FOSSILS, ABERDEENSHIRE.

\section{Baljik.}

Helix ; (in the same packet as No. 5, but the matrix of the Helices, as seen by their contents, was sandy).

7. Fossils from the Dardanelles. (Hard brownish rock.)

Cypridæ.

Cardium.

Paludina? and Opercula?

Unio?

\section{Dardanelles; (grit).}

Paludina.

Unio.

Cyrena?

9. Dardanelles; (sandy rock).

Paludina.

Cyrena.

10. Dardanelles; (fissile brownish calcareous sandstone). Cypridæ.

Cardium.

Unio.

11. Dardanelles; (rock similar to No. 10, but more crystalline).

Ligneous fossils (referred to above, p. 81).

12. Dardanelles; Europe Castle.

Melanopsis (see page 81).

13. Dardanelles. (See page 82.)

Cardium.

Dreissena.

On the Cretaceous Fossils of Aberdeenshire. By J. W. SAlter, Esq., F.G.S. With a Note on the position of the Chalkflints and Greensand; by W. Ferguson, Esq., F.G.S.

[Read June 18, 1856*.]

[Plate II.]

No apology need be offered for presenting to the Society a list of the cretaceous fossils discovered in Aberdeenshire by $\mathrm{Mr}$. W. Ferguson, and figures of the new and characteristic species; for there are many points of interest connected with the former extension of the cretaceous rocks from Sweden over the northern part of Britain, and thence to the north of Ireland, which must receive illustration by the recording of such facts as those which he has observed. (See Appendix, p. 88.)

His own impression is, that there might be a possibility of the fossils in question having been drifted to their present position. But,

* For the other communications read at this Evening's Meeting, see Quart. Journ. Geol. Soc. vol. xii. p. 384, \&c. 